\title{
COVID-19, the Anthropocene, and the Imperative of US-China Cooperation
}

\author{
Tong $\mathrm{Wu}$ \\ State Key Laboratory of Urban and Regional Ecology, Research Center for Eco-Environmental Sciences, Chinese Academy of Sciences, Beijing 100085, \\ China
}

It is widely acknowledged that cooperation between the USA and China, the world's two largest economies, is crucial to global peace and sustainability (Bi et al. 2014). But as a recent article in EcoHealth persuasively argues, USChina cooperation in research and policy is also essential to global health (Smiley Evans et al. 2020). In this article, international leaders from key disease research groups in both countries stated: "China and the USA are well placed to lead efforts in emerging infectious disease (EID) preparedness both from a national interest standpoint, resource availability and a global health interconnectedness perspective". Therefore, amidst the worst pandemic in recent history, it is profoundly worrying that this crucial bilateral relationship has been characterized more by recrimination than cooperation.

Scientists and public health officials on the frontlines of the COVID-19 pandemic in China have been targeted with insults and conspiracy theories, by domestic opponents and by public figures in the USA. The spread of disinformation, particularly with respect to the outbreak's origins, will make it more difficult to adopt the earnest scientific approaches needed to prevent future pandemics. But even before the outbreak, fracturing US-China relations undermined infectious disease preparedness. Most notably, the USA withdrew its embedded expert at the China Center for Diseases Control and Prevention in 2019

Published online: October 28, 2020

Correspondence to: Tong Wu, e-mail: tongwu15@outlook.com
(Reuters 2020). The role was meant to streamline coordination between the two countries, and its services would have been particularly useful to both sides during the COVID-19 outbreak.

Nonetheless, there have been flickers of brightness in the geopolitical gloom. The international inpouring of experts and supplies to Wuhan was later mirrored by the large-scale outpouring of medical materiel and personnel to the rest of the world by China. The Lancet recently published a clarion call of support for Chinese scientists, medical professionals, and public health professionals by their international colleagues, hailing the former's "remarkable" efforts and strongly condemning conspiracy theories about COVID-19's origins (Calisher et al. 2020). And the timely exchanges of data by researchers across the world have been critical to the development of diagnostics, medical treatments, and epidemiological modelling. Such examples of cooperation should be the norm for international relations, even beyond the present period of COVID 19-induced emergencies.

But unfortunately, the deterioration of US-China relations in recent years has prompted commentators to warn ominously of a "New Cold War" or revive the hoary duality of "East versus West". Behind many of these assertions is the belief that US-China confrontation is a kind of historical inevitability, as in the notion of the "Thucydides Trap" (Allison 2017). But to successfully navigate the risks of the Anthropocene, the calculus of national interest needs to change. In the context of EID 
risks, the "national interest standpoint" discussed by Smiley Evans et al. (2020) reflects the fact that an outbreak anywhere can quickly become a pandemic everywhere. Countries should not seek to maximize relative gains in a shrinking and interconnected world. Instead, they should seek to protect and expand what scholars have aptly termed "a safe operating space for humanity" for current and future generations (Rockström et al. 2009). The COVID-19 pandemic has shown the undeniable reality of this shared operating space and how suddenly and gravely its safety can be undermined.

Mitigating pandemics, like slowing climate change and safeguarding the planet's life-supporting ecosystems, is an essential global public good-and it can only be provided through international cooperation. In recent history, perhaps only the prevention of nuclear proliferation evokes a similar level of urgency. In the waning years of the Cold War, the leaders of the USA and Soviet Union met in Geneva to advance nuclear disarmament. Attempting to evoke a sense of common purpose, Ronald Reagan was said to have told Mikhail Gorbachev that the two rival superpowers would certainly join forces if the world was invaded by extraterrestrials. Perhaps more than the ancient wisdom of Thucydides or superficial distinctions between "East" and "West", this metaphor of common humanity best captures the world's most pressing challenges.

H. G. Wells, whose The War of the Worlds famously imagined humanity's struggle against a Martian invasion, once wrote: "Human history becomes more and more a race between education and catastrophe". In our own time, catastrophe has been racing ahead. As educators-of ourselves and others, whether through research, teaching, or activism-we must continue to promote international cooperation for global health, a prospect that is implausible without US-China cooperation. In the Anthropocene, individuals, communities, and nations need to set aside their antagonisms and jointly confront the threats facing the planet. As the COVID-19 pandemic has shown, the Martians are already here-and there may be more invasions to come.

\section{REFERENCES}

Allison G (2017) Destined for War: Can America and China Escape Thucydides's Trap?, New York: Houghton Mifflin Harcourt

Bi J, Young O, Costanza R, et al. (2014) Same dream, different beds: Can America and China take effective steps to solve the climate problem? Global Environmental Change 24:2-4

Calisher C, Carroll D, Colwell R, et al. (2020) Statement in support of the scientists, public health professionals, and medical professionals of China combatting COVID-19. The Lancet 395:E42-E43

Reuters (2020) Exclusive: U.S. axed CDC expert job in China months before virus outbreak. Available at: https://www.reute rs.com/article/us-health-coronavirus-china-cdc-exclusiv/exclusiveu-s-axed-cdc-expert-job-in-china-months-before-virus-outbreak-i dUSKBN21910S (Accessed July 4th 2020).

Rockström J, Steffen W, Noone K, et al. (2009) A safe operating space for humanity. Nature 461(7263):472-475

Smiley Evans T, Shi Z, Boots M, et al. (2020) Synergistic ChinaUS ecological research is essential for global emerging infectious disease preparedness. EcoHealth 17:160-173 